\title{
The Contribution of Forest Products to Dryland 管 Household Economy: The case of Kiang'ombe hill forest, Kenya
}

\author{
Grace Ngugi, Leonard E. Newton and Muthama Muasya
}

\section{Research}

\begin{abstract}
An integrated approach of participatory rural appraisal (PRA), participatory environmental valuation (PEV), household survey, group discussions and forest walks with knowledgeable people was used in an ethnobotanical survey of Kiang'ombe hill forest in Mbeere District of Kenya. Ten forest uses were identified with the highest dependence being in the supply of building materials and medicine, the latter having the highest average annual household value of KSh. 2953 (US\$47). The average annual household forest value was calculated at KSh. 16,175.6 (US\$256.80), accounting for $55.4 \%$ of household income. Use of PEV in Kiang'ombe, where there were no formal records of forest use, was important in assigning monetary value to biodiversity elements essential for survival that were assumed to be free for the taking. The assigned monetary value gives weight to otherwise non-monetary values recognized by local communities but ignored because they do not enter formal markets. PEV is one of the recommended methods for estimation of forest resources' value in a non-cash economy.
\end{abstract}

\section{Introduction}

Many rural communities have difficulties in meeting subsistence needs, especially when rains fail, and rely on the forest for livelihood. The forest adjacent communities or those living in the forests have a longer history in not only depending on the forest for their services and functions but also for extraction of biological materials, both for human and livestock use.

The major justification for forest conservation has been to preserve their ecological values either as major watershed areas or as habitat for diverse range of plant and animal species. This is especially weighted by those that are rare or endangered. Previously there was no empha- sis on conservation for forest livelihood values (Emerton 1997a,b). However, in the recent past, there has been a paradigm shift towards understanding the significant contribution that ecosystems, vegetation and biodiversity resources make to local livelihood economies as well as the values of the services they provide in maintaining functions that are vital to human well-being.

Most Kenyans live below the poverty level of $\$ 1$ a day with $50 \%$ of the population estimated (in 2000) to live below the poverty line, and a household income or consumption by percent share estimated in 2005 to be $1.8 \%$ for the lowest $10 \%$ and $37.8 \%$ for the highest $10 \%$ (World Factbook 2010). With frequent droughts experienced in the country, millions of people are put at risk for survival and forest resources therefore secure their livelihood. There is not much research done in the country to give an exact estimate of the contribution of these resources to household economy at the national level. The few studies conducted (see Emerton 1996b,c, 1997a), show the importance of

\section{Correspondence}

Grace Ngugi, East Africa Herbarium, National Museums of Kenya, P. O. Box 46155, Nairobi 00100, KENYA.

grace.ngugi@yahoo.com

Leonard E. Newton, Department of Plant \& Microbial Sciences, Kenyatta University, P.O. Box 43844, Nairobi 00100, KENYA.

Muthama Muasya, Department of Botany, University of Cape Town, Private Bag 7701 Rondebosch, SOUTH AFRICA.

Ethnobotany Research \& Applications 9:163-180 (2011)

Published: April 20, 2011 
forest resources at the local level, which may explain survival on low incomes.

Some of the forests supporting people especially in the drylands are small fragments existing as islands on top of inselbergs and any population pressure on the resources is significant. Kiang'ombe hill forest is one such fragment. It is restricted to steep slopes and mountaintop, and is a mature forest with very little apparent regeneration. Some species found there could be threatened as they do not occur on lower slopes, which are subjected to frequent fires, and a record of their presence could help in developing conservation strategies for the area.

Kiang'ombe Hill forest (Figures 1, 2 ), lying at longitude $37^{\circ} 42^{\prime} 52^{\prime \prime}$ East and latitude $0^{\circ} 34^{\prime}$ South, is situated to the south eastern side of Mt. Kenya, about $30 \mathrm{~km}$ due east of Embu town and occupies parts of Evurore and Siakago Divisions of Mbeere District, one of the thirteen districts that form Eastern Province of Kenya. It is an indigenous forest, with less than $5 \%$ exotic plantations both at the foot and top of the hill, and rises from about $1000 \mathrm{~m}$ to $1800 \mathrm{~m}$ above sea level.

A larger proportion of the land is under secondary forest, especially on the lower slopes, covered by bushland and wooded grassland. The
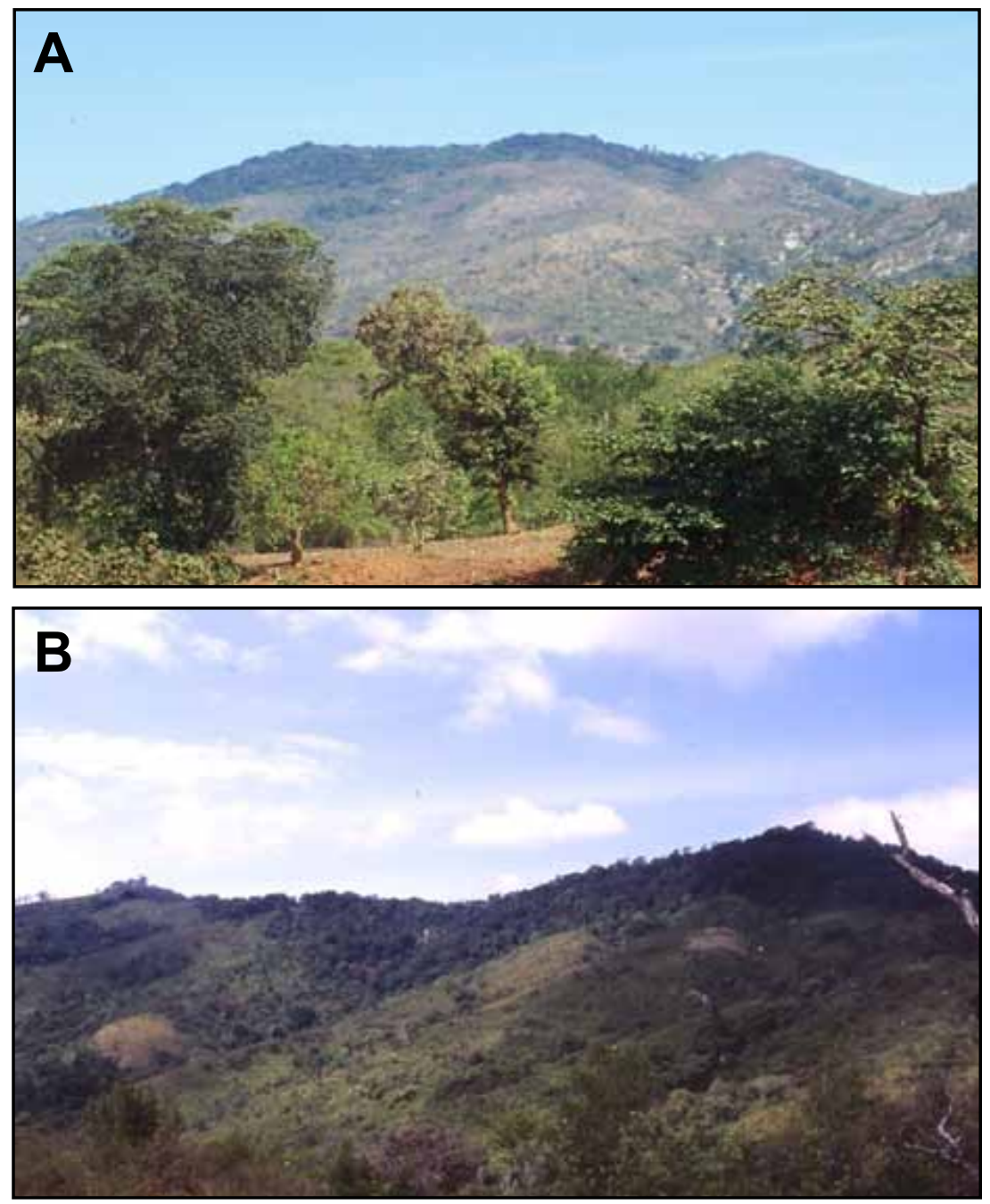

Figure 1. Kiang'ombe hill from the north, showing the closed canopy forest at the top and secondary vegetation on the slopes (2005): (A) recovering from fire, taken from $8 \mathrm{~km}$ distance; $(B)$ closer view of the hill taken on the northern slope.

bushland and wooded grassland stretches from about $1300 \mathrm{~m}$ altitude to about $1548 \mathrm{~m}$, while the closed canopy forest stretches from $1548 \mathrm{~m}$ to $1800 \mathrm{~m}$. Mbeere District Development Plan 2002-2008 (GoK 2002, Wass 1995) show the forest area to consist of about 2104 ha and 1427 ha respectively, the latter estimate following the limits of closed canopy forest cover as identified from satellite imagery, contrary to Beentje (1990) who estimates the total forest area to be about 150 ha, probably considering the closed canopy forest at the top of the hill only, and the vegetation type is Ocotea forest. The upper parts of the hill are covered by almost pristine moist evergreen forest albeit one small area at the top east end of the hill has an exotic plantation, about $200 \mathrm{~m}^{2}$ of Acacia mearnsii De Wild. Besides, the western lower edge of the closed canopy moist forest has a small plantation of Eucalyptus spp. extending to the bottom of the hill.

Kiang'ombe hill has ecological, cultural, and probably commercial significance in Mbeere District. It forms a major water catchment area from which five streams rise, some of which are tributaries of Tana River, the biggest river in the country flowing to the Indian Ocean that holds the country's most important hydropower plants producing $50 \%$ of Kenya's total electricity output. Two of the streams rising from Kiang'ombe are tapped to serve lower parts of Kiang'ombe and Siakago areas. There are sacred sites within the forest where traditional rituals and customary activities are performed.

The forest is surrounded by an ever-increasing population that is persistently encroaching on it. As a result, there is anthropogenic disturbance such as subsistence cultivation, charcoal production and frequent forest fires set by the adjacent community annually in preparation for the 


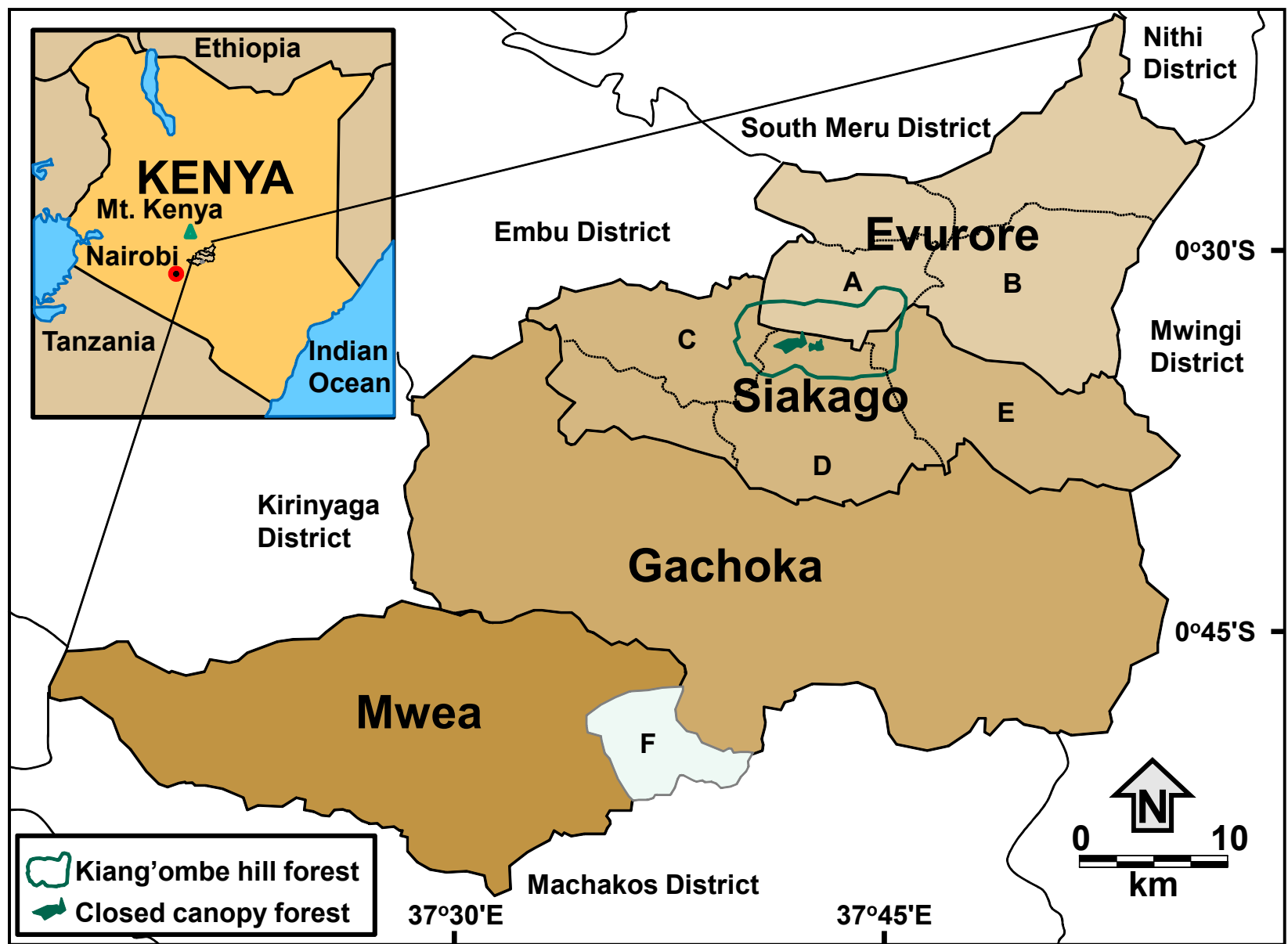

Figure 2. Mbeere District, Kenya with Kiang'ombe hill forest, Closed canopy forest, administrative subdivisions of Evurore [Kiang'ombe (A) and Ndurumori (B)] and Siakago [Nthawa (C), Muminji (D) and Mutitu (E)], and Mwea National Reserve (F).

rains. Kiang'ombe hill forest is a trust land, managed by the local county council, and whose management is poor. The Trust Land Act of the Kenyan Constitution makes provision for general conservation, protection and controlled utilisation of trees and other forest products on land, other than gazetted forest reserves (Matiru 2000). However, due to lack of proper implementation of the policy, poor management and lack of control, forests under Trust Land tenure in Kenya are generally exposed to over exploitation and unequal access to products and benefits by the adjacent communities. It is known from literature that forest adjacent communities benefit from the forests but also pose a threat to them from their activities if there are no control measures in place. The problem is exacerbated if there are market demands for the various forest products. It is therefore important to find out about collection processes, to help understand what measures are needed to ensure that the forest products are removed without damaging a conservation area's biodiversity. If the causal agents of the loss of forests are understood, it is possible to develop methods to reverse the trend (Groombridge 1992).

At the time the study was being conducted, proposals had been made to have the Kenya Forestry Services (KFS) help manage the forest, who in turn imposed a rule against grazing, charcoal burning or collection of firewood from the forest. Unfortunately, KFS could not successfully halt these activities, mainly because the management planning had not been done and there were issues pertaining to land tenure (Mbeere district forest officer pers. comm). In order to carry out management planning of a forested area, there is need to carry out some surveys including socio-economic and floristic among others. There was no known survey prior to this study even to determine the dependence of the local people on Kiang'ombe hill forest or how they value its resources.

This study, sought to determine the value of Kiang'ombe hill forest to the local community by valuing the plant products extracted from it and activities held within it. The 
supposition of the study was that Kiang'ombe forest has plants with diverse uses by local people which make a substantial contribution to the household economy of the people living around it. Hence, the objective was to determine the plant usage by the Mbeere people living near Kiang'ombe hill forest, and then estimate the value and contribution of the forest products to households.

\section{Forest products valuation}

Rural communities living around forests harvest a diversity of wild resources for home consumption and sale (Groombridge 1992, Shackelton et al. 2002). This extraction of the wild resources, and the use of forest service functions that fulfil different roles in the peoples' sustenance, allow them to live with less cash (Delang 2006). Delang (2006) observes that the consumptive use of the non-timber forest products (NTFPs), like fuelwood, fodder, herbals, food, attract much less attention than their commercial use, and yet they "play a more important role in the livelihood of the population than the cash earned with the sale of NTFPs or other commodities." Arguably, the contribution these make to the rural economy has been little recognized, and few studies have attempted to place a monetary value to it (Emerton 1997a, Godoy et al. 1993, Shackelton et al. 2002), which has been found to be of limited validity in subsistence economies (Emerton 1997a, Rosales et al. 2003). There are several methods that have been developed for monetary valuation of different levels of biodiversity, most of which have been widely tested in developed countries with strong market traditions, with particular attention given to methods developed from the perspective of conservation and sustainable use of biodiversity (Godoy, et al. 1993, Nijkamp et al. 2008, Nunes \& van den Bergh 2001). Delang (2006) notes that it is relatively easy to give a monetary value to the NTFPs that are sold, but in the absence of markets for these products, the methods of evaluation are not straight forward. He further observes that 'while environmental and ecological economists have done extensive research on hypothetical markets, the techniques they have developed are not always suitable to estimate the values of non-marketed NTFPs.' In the following section, effort has been made to review some of the methods used for non marketed forest products that can be applicable in our study area. These include contingent valuation (CV), substitute products value (SPV), opportunity cost of time used in collecting NTFPs and participatory environmental valuation (PEV). Chopra (1993) describes economic evaluation techniques for estimation of the value of non-timber goods and services, including soil conservation, nutrient recycling through litter fall, preservation of biodiversity, maintenance of hydrological cycle - which some people consider NTFPs (Delang 2006), but they are beyond the scope of this paper.

\section{Contingent Valuation}

This is one of the stated preference valuation techniques that are based on collecting data by means of questionnaires in an attempt of retrieving consumers' preferences (Nunes \& van den Bergh 2001). In this method, researchers try to find out the willingness of consumers to pay for biological resources, how much they would be willing to sell them or their willingness to accept compensation for losing them (Delang 2006, Godoy et al. 1993). However, this has limitations in that (i) it is difficult to give a price for something that has always been free (Delang 2006), (ii) in Kiang'ombe, barter trade is still practised where the value of goods exchanged vary in value per individual and exchanges are not standard (one can exchange a chicken for herbal medicine while another can offer one container of honey - locally known as kĩthembe, for the same), (iii) as Delang (2006) points out, households might feel under pressure to value the gathered resources and as a consequence, invent a figure to please the interviewer, and (iv) comparing answers given by interviewees poses a problem because some may give the 'exchange value' while others give 'use value' of their products (Delang 2006). In addition, according to Godoy and Lubowski (1992), CV was designed for valuing goods with markets and assumes that the value people quote as willing to pay is the value they would actually pay, and therefore the method 'is of limited use in non-monetized economies'.

\section{Time needed to collect the forest products}

This may be considered an extension of the travel cost method (Delang 2006), a method classified together with hedonic price and wage rate as revealed preferences techniques, used by environmental economists to elicit preferences from actual, observed market-based information. It involves measuring the time spent by people collecting NTFPs and then giving a monetary value to the time using the local wage rate (Delang 2006). This calculates opportunity cost of time spent gathering NTFPs and has limitations in that (i) it is difficult to calculate the exact time spent collecting as this is done sometimes when people are on other duties or missions (Delang 2006), (ii) it is time consuming especially if one opts to use participant observation approach, which in itself is not always accepted by people as it touches on knowledge that is sometimes considered the preserve of specialist groups particularly in forests that are of cultural significance, and given that most forest uses are illegal (Delang 2006, Emerton $1996 \mathrm{~b})$ and (iii) value of time may differ among a people (Delang 2006).

\section{Substitutes Products Value (SPV)}

This has been described well by Godoy et al. (1993) and Gunatilake et al. (1993). It uses some characteristics of marketed products to estimate the prices of similar NTFPs. Godoy et al. (1993) prescribe the approach whereby 


\section{Ngugi et al. - The Contribution of Forest Products to Dryland Household Economy: The case of Kiang'ombe hill forest, Kenya}

one establishes a relative price between the priced and unpriced products on the basis of product characteristics, while Gunatilake et al. use a similar approach to calculate the value of NTFPs that have no price in either the village or the market, but have close substitutes with value in the village. The SPV method presents limitations in that it is difficult to identify products that are close substitutes when all factors are taken into account like scarcity, taste, size, social attributes (Delang 2006) and one is in a dilemma whether to use the price of the substitute products that are sold or bartered within the village (this is influenced by other socially rooted interactions) or the sale price in the market (Chopra 1993, Delang 2006).

In addition, the methods as described by Godoy et al. (1993) and Gunatilake et al. (1993), vis-à-vis pricing for valuation, present other limitations for use in the study area addressed in this paper in that (i) there are no local markets at which substitutes are available or affordable, (ii) asking people for their cash willingness to pay (or to be compensated) for forest resources is inappropriate in a non-cash economy where livelihoods depend on irreplaceable forest resources, (iii) the majority of the rural population do not keep records of forest use, (iv) forest use is season dependant, and (v) in most cases forest use is illegal and involves privileged knowledge (Emerton 1997a,b). Due to these limitations, environmental economists have developed alternative methods for forest valuation that suit the area under study. One such outcome is the development of a participatory technique, participatory environmental valuation (PEV).

\section{Participatory Environmental Valuation}

This method is an extension of the contingent valuation, which seeks to address the problem of pricing non marketed products used for subsistence. It aims at finding a bridge between local economic systems and cash values, and eliciting information about forest use and values at the subsistence, non-market level by removing money from the analysis and introducing a yardstick for comparison. This yardstick, a basic standard by which values are measured in a monetary system, generally referred to as 'numeraire', consists of a commodity that has wide local significance as an item of value and can be translated into a monetary amount easily as its value is relatively fixed and known to all (Delang 2006, Emerton 1996c). The method follows a three-stage process; ranking, establishing of values by use of counters, and identifying the purchase price of the numeraire commodity (Emerton 1996a,c). These can then be discounted to give average annual household use values at today's prices. Emerton (1996a,b,c, 1997b) uses this method to evaluate the relative importance of a broad range of forest products/activities, from 'conventional' NTFPs like hunting, fuelwood, foods, medicines, honey, utility items, through 'non-conventional' NTFPs like grazing, water, building \& construction materials, to timber. Both the range of forest activities depicted and the numeraire selected vary between different forest using communities, as this is dictated by a people's culture. Consequently, Emerton has used castrated bullock, milk cow, and radio as numeraire in different studies as components of the local economy. However, this method has a few limitations in that (i) a yardstick with a known value might not always be available (Delang 2006) and (ii) respondents might not be able to decide the fraction of the yardstick a forest product would be exchanged with (Delang 2006).

\section{Study Area and Methodology}

\section{Climate}

The area is semi-arid, receiving an average annual rainfall of $550 \mathrm{~mm}$ (GoK 2002), which is a drastic fall from that reported over the period from 1949 to 1977 of $1072 \mathrm{~mm}$ with rain falling on average 66 days annually (Riley \& Brokensha 1988). The rainfall pattern is bimodal with long rains experienced between April and June (with an average of $172 \mathrm{~mm}$ ) and short rains from October to December (with an average of $363.2 \mathrm{~mm}$ ), but is not reliable (GoK 2002). The altitudinal range influences the temperatures, which average at $23^{\circ} \mathrm{C}$ and range from $20^{\circ} \mathrm{C}$ to $32^{\circ} \mathrm{C}$ with July, the coldest month, having an average monthly temperature of $15^{\circ} \mathrm{C}$, and September, the warmest month, with average temperature of $30^{\circ} \mathrm{C}$ (GoK 2002).

\section{Population and land use}

Mbeere district has a total population of 170,953 people (CBS 2001), the most populated divisions being Siakago and Evurore with 100 and 96 persons per $\mathrm{km}^{2}$ respectively. [This figure may appear low by global standards, but the calculations here indicate a carrying capacity even where land is uninhabitable like hills, where persons are precluded from habitation.] Evurore division has the highest number of poor people, with the majority of the poor being found in Ndurumori and Kiang'ombe locations (administrative sub-divisions) while the poorest people in Siakago division are found in Mutitu and Muminji locations (GoK 2002), all of which are adjacent to Kiang'ombe hill (Figure 2).

Land use activities of the people living around Kiang'ombe hill include bee-keeping, livestock farming (where farmers keep a local breed of Zebu cattle and goats) and subsistence farming with main food crops produced being maize, sorghum, millet, pigeon peas, cow peas and green grams. The north side of the hill receives more rainfall and has more productive soils, consequently cash crop farming is practised, with main cash crops being tobacco, cotton, and sunflower. 


\section{The Mbeere people}

Mbeere are a bantu-speaking people whose language, ki-Mbeere, is closely related to Gikuyu, Kamba and kiEmbu. They neighbor Meru people to the north, Kamba to the east, south and southeast, Embu to the northwest and Gikuyu to the west. The area they occupy is characterized by periodic drought and famine, survival in which made them develop a rich and wide knowledge of their environment, and especially of the vegetation. There has been little in Mbeere history which has distracted the people's attention from their natural habitat hence, they have a detailed and intimate knowledge of the plants (Riley \& Brokensha 1988). Traditional knowledge on use of local biological resources remains/is active among the people, with minimum influence of external cultures, so much such that even in sickness, they first resort to plants. It is therefore not surprising that plant use knowledge is widespread among the Mbeere, irrespective of age.

\section{Methods}

An ethnobotanical survey was carried out mainly in three locations around Kiang'ombe hill, to determine plants used and products/services extracted by local communities. These locations are Kiang'ombe (in which approx- imately $50 \%$ of the forest falls), Mutito (approximately $25 \%$ ), and Nthawa (approximately 15\%). The study involved the use of several tools and methods to collect as much actual data as possible. These included participatory rural appraisal (PRA), discussions and forest walks with knowledgeable local people and household surveys using questionnaires. Observation of forest products usage including grazing, flow of resources like honey, farming activity within the forest area and general movement to the forest was made and brought to discussions either during household interviews or forest walks with knowledgeable people.

Household surveys were done in thirteen villages: 10 villages in Kiang'ombe location of Evurore division and 3 villages in Nthawa location of Siakago Division. Households directly adjacent to the hill and up to $5 \mathrm{~km}$ from the forest border were randomly chosen and questionnaires administered in the local language. For better interaction and complete assessment of usage of plants, the interviews and general discussions were made at the respondents' homestead, lasting an average two hours.

Specific information sought during the interview and listing exercise included plants used, how used, parts used, methods of harvesting, ease in getting these plants (to

Table 1. Wealth ranking criteria used in Kiang'ombe hill forest area of Mbeere District, Kenya.

\begin{tabular}{|c|c|c|c|c|}
\hline Criteria & Well off & Comfortable & Poor & Very Poor \\
\hline Income & Regular & Regular & Erratic & Lacking \\
\hline Source of Income & Salary/Self employed & Salary/Self employed & Casual labourer & Not verifiable \\
\hline Food source & $\begin{array}{l}\text { Entirely from own in- } \\
\text { come or on farm pro- } \\
\text { duction }\end{array}$ & $\begin{array}{l}\text { From own income or } \\
\text { on farm production } \\
\text { with occasional for- } \\
\text { est gathering }\end{array}$ & $\begin{array}{l}\text { own income or on } \\
\text { farm production plus } \\
\text { supplements from } \\
\text { forest gathering, } \\
\text { govt. \& NGO relief }\end{array}$ & $\begin{array}{l}\text { mainly rely on forest } \\
\text { supplements, govt. \& } \\
\text { NGO relief }\end{array}$ \\
\hline $\begin{array}{l}\text { Meet Clothing Needs } \\
\text { for the family }\end{array}$ & Adequately & Adequately & Inadequately & $\begin{array}{l}\text { School going chil- } \\
\text { dren depend on } \\
\text { NGO for clothing }\end{array}$ \\
\hline Type of house & Permanent & $\begin{array}{l}\text { Permanent/Semi- } \\
\text { permanent }\end{array}$ & Temporary & Temporary \\
\hline Roof type & $\begin{array}{l}\text { Bricks/Corrugated } \\
\text { Iron Sheet }\end{array}$ & $\begin{array}{l}\text { Bricks, Corrugated } \\
\text { Iron Sheet, Metal- } \\
\text { lic sheets or tins and } \\
\text { sometimes thatch }\end{array}$ & $\begin{array}{l}\text { Corrugated Iron } \\
\text { Sheet, Metallic } \\
\text { sheets or tins, thatch }\end{array}$ & thatch \\
\hline Wall type & Walls of masonry & $\begin{array}{l}\text { either Walls of ma- } \\
\text { sonry, cement plas- } \\
\text { tered clay bricks, ce- } \\
\text { ment plastered earth- } \\
\text { en walls }\end{array}$ & $\begin{array}{l}\text { Earth walls plastered } \\
\text { with clay/stick walls }\end{array}$ & $\begin{array}{l}\text { unplastered and } \\
\text { poorly maintained } \\
\text { earth walls/stick } \\
\text { walls }\end{array}$ \\
\hline Land size & Significant & Significant & Significant & Insignificant \\
\hline $\begin{array}{l}\text { Meet Primary Educa- } \\
\text { tional needs }\end{array}$ & Comfortably & Comfortably & $\begin{array}{l}\text { Require additional } \\
\text { aid like bursary }\end{array}$ & $\begin{array}{l}\text { Entirely dependent } \\
\text { on government or } \\
\text { NGO aid }\end{array}$ \\
\hline
\end{tabular}




\section{Ngugi et al. - The Contribution of Forest Products to Dryland Household Economy: The case of Kiang'ombe hill forest, Kenya}

give an indication on abundance and distribution), whether for personal use or traded, monetary value (where applicable), when collected, by whom and general view on conservation and management of the forest (Appendix 1).

Household wealth ranking was used to determine whether wealth has any effect on plant usage. Lists of households in each village, provided by the area chiefs, were used as a frame for random sampling. Household wealth ranking was done with the help of the sub-areas (a term used for locally elected village elders who report to the assistant chief) and three local people in each village. The households to be visited were sorted into four groups using the wealth ranking criteria (Table 1 ) as established by the local people; (i) well off, (ii) comfortable, (iii) poor and (iv) very poor. Issues considered by the villagers in ranking were whether (i) the household head had a regular source of income, even if from relatives, (ii) household head was engaged in any income earning activity within the village, (iii) depended entirely on the forest resources or (iv) on government relief food. Land size and its yield was considered, but was not of major consideration in the local people's wealth ranking. People who were able to feed their families and pay for primary educational needs, like school uniforms and writing materials, were regarded as comfortable, while those who depended on government and local NGOs for these were said to be poor. A few who did not meet these criteria were said to be very poor if they were unable to meet even their basic needs including housing; or whose land was thought to be of little value. Owning a house with walls of masonry and iron sheet roofing was regarded as an indication of wealth and the few who had such houses in addition to regular income were ranked as well off or rich (see Table 1).

The forest contribution to the household economy was estimated using the methods of Martin (1995), Cunningham (2001) and Emerton (1996a). Wealth ranking, done during group discussions with village elders, livelihood analysis and household survey for plant usage and annual family earnings using data gathered during direct interviews was used to estimate average household resources.

\section{Determination of Forest Exploitation and Value}

During the PRA meetings, participants were asked to identify and rank the forest uses, value them by assigning number of counters equivalent to the importance to them and identify a numeraire, its average lifespan and its market price. Using pieces of sticks as counters, the values of each use, including of the numeraire, were established. Sketches of the forest products identified were each done on manila papers. A sketch of the numeraire chosen was also done, and using sticks, participant were asked to place them against each of the forest products according to how they value them, including on the numeraire. Using the number of sticks placed on each product, the wealth item equivalent was established by dividing the number of sticks placed in each product with that of the numeraire. The cash amounts equivalent to the products were then calculated by multiplying the wealth item equivalent with the market price of the numeraire, which were then discounted to give annual forest use values using the formula:

$$
1 / T \sum_{t=1}^{t=T}\left[V / T(1+r)^{(T-t)}\right]
$$

where $T$ is the total lifetime of the wealth item, $V$ the value of the forest activity, $r$ the discount rate and $t$ the year. (see Table 4).

\section{Observation}

Throughout the study period, observation of forest activity or resource use or extraction was recorded as encountered. Where a resource use or activity was found to be unsustainable or was deemed illegal as stipulated by the Kenya Forest Service district office, it was brought to discussion either during forest walks, interviews or focus groups discussion, for better understanding.

\section{Results and Discussions}

In total, 90 households were interviewed. The wealth ranking as carried out here was found to be flawed in that personal relationships between the people assisting in ranking with the interviewees influenced their ranking, and in six cases the opinion of the researcher differed from that of the villagers after visiting the households.

The average family size in Kiang'ombe is seven members with an average five acres of land, Table 2. The forest dependency as reported in the questionnaires is shown in Table 3. The on-farm tree resources and other assets on the livelihood platform, other than those recorded on the table, were converted to monetary value and included in the calculation of the total annual income. The highest dependence on the forest was found to be in the supply of building materials and medicine, both human and veterinary.

Table 2. Average household resources in Kiang'ombe hill forest area of Mbeere District, Kenya..

\begin{tabular}{|l|l|}
\hline Resource type & No./Size \\
\hline Land Owned & 5.01 acres \\
\hline Family size & 7 \\
\hline Chicken & 7 \\
\hline Goats & 4 \\
\hline Sheep & 0.2 \\
\hline Cows & 1.2 \\
\hline Donkeys & 0.3 \\
\hline Annual income & 29185.72 (US\$ 463.3) \\
\hline
\end{tabular}


Table 3. Household dependency on Kiang'ombe hill forest, Mbeere District, Kenya.

\begin{tabular}{|l|c|c|}
\hline Forest use & $\begin{array}{c}\text { Number of } \\
\text { households }\end{array}$ & $\begin{array}{c}\text { \% of the } \\
\text { total }\end{array}$ \\
\hline Grazing & 25 & 28 \\
\hline Thatch & 31 & 34 \\
\hline Bee farming & 45 & 50 \\
\hline Food & 45 & 50 \\
\hline Building material & 88 & 98 \\
\hline Timber & 71 & 79 \\
\hline Hunting & 18 & 20 \\
\hline Fibre & 27 & 30 \\
\hline Fuel wood & 46 & 51 \\
\hline $\begin{array}{l}\text { Veterinary } \\
\text { medicine }\end{array}$ & 72 & 80 \\
\hline Human medicine & 77 & 86 \\
\hline
\end{tabular}

\section{Forest Exploitation and Value}

Ten forest uses were identified during two PRA meetings, one on the northern and the other on the southern side of the hill. The bicycle was used as numeraire in accordance with the method described by Emerton (1996a) and Rosales et al. (2003).

The forest uses identified and ranked high were timber, medicines, honey, building materials, food, hunting, grazing, charcoal, firewood, and khat (Catha edulis Forssk., also known as mĩraa in Mbeere language) harvesting. In Soko Mjinga, the uses were ranked as medicines, building materials, firewood, honey, grazing, food, khat, hunting, charcoal, and timber, in that order. At Kirie, medicine, building materials and food were ranked equally to Soko Mjinga. Timber was ranked third, firewood and charcoal fourth and fifth, hunting and grazing seventh and eighth, honey ninth and khat tenth. In both cases, ranking was based on relative importance of the commodity to the people and on relevant immediate use. To the majority of people in this area, conventional medicine comes second to traditional medicine and hospitals were said to be far and expensive. Similarly, the communication network was poor and therefore people relied on locally available commodities. Mbeere is a dry area and prolonged drought has made people resort to hunting in the forest for bushmeat.

During the valuation process, counters equating the forest products to their importance were used to allocate points for the product. The value of these products was compared with the value of the bicycle in the local economy. The value of a bicycle was estimated to be KSh. 3000 (US\$47.6), with a discount rate of $3 \%$, and a bicycle lifespan of about 5 years. This was used to calculate use values as shown in Table 4. The forest use most valued in Soko Mjinga and Kirie was medicine with an average annual household value of KSh. 2624.84 (US\$41.7) and KSh. 3281.05 (US\$52.1) respectively (calculations based on nominal values). The forest provision of medicine, building materials, khat, bush meat, charcoal and timber was more valued in Kirie, while provision of firewood, honey and pasture were more valued in Soko Mjinga. The forest's provision of food was valued equally in the two areas with an average annual value of KSh. 1312.42 (US\$20.8) per household. Table 4 shows the calculation of average annual values of the forest uses.

In the calculations shown above, it was assumed that the numeraire undergoes a single depreciation irrespective of inflation and other external monetary forces (simple ware \& tare), thus being an example where the PEV method using a numeraire has limitations.

Superficially it seems that the forest is more valued for provision of primary human needs like food and housing in Kirie, and for secondary needs in Soko Mjinga. But in reality, Soko Mjinga is on the wetter northern side of the hill, on the main road to the major towns in the district and is much nearer to the forest. In addition, the forest is more accessible from this side, thus making provisions of the primary requirements more available. Kirie is on the drier southern side of the hill where the terrain of the hill is broken, and therefore, it is more difficult to access the forest resources, thus increasing their value.

Notably in the discussion, people were not willing to value the use of Kiang'ombe hill forest for rituals and cultural ceremonies (one in appeal for rain was held at the time of the study). When pursued to do so, they said that the value was above the wisdom of most participants and required the community sages' wisdom and advice as this was their preserve.

Forest resources thus prove to be an important source of non-cash income for Kiang'ombe households particularly for the poorest people. Barter trade is practised occasionally, especially in traditional medicine and in land leases where one pays the owner of the land by planting an agreed number of trees. The realization of this non-cash dependency for livelihood prompted the use of market standard equivalent methods to evaluate the importance of the forest to the people of Kiang'ombe.

The value of a forest and estimation of its exploitation is best realized by interacting with and observing the activities of people living around this resource reservoir (Guijt \& Hinchcliffe 1998). Where possible, accompanying resource users into the field to observe parts gathered and gauge the volume of harvest is the most accurate method (Emerton 1996b, Martin 1995, Padilla \& Rina 1998, Waiganjo 1999). However, this is time consuming and can be very challenging if several forest resources are being considered, as was the case for Kiang'ombe hill for- 


\section{Ngugi et al. - The Contribution of Forest Products to Dryland Household Economy: The case of Kiang'ombe hill forest, Kenya}

Table 4. Average annual household forest use values (in KSh.), Kiang'ombe hill forest area, Mbeere District, Kenya. Average annual value was calculated using the formula: $t=T$

$$
1 / T \sum_{t=1}\left[V / T(1+r)^{(T-t)}\right]
$$

with the value of $t$ ranging from $t=1$ to $t=T$, where $T$ is the total lifetime of the bicycle, $V$ the value of the forest activity, $r$ the discounted rate and the year. The value of a bicycle was estimated to be KSh. 3000 (US $\$ 47.6$ ), with a discount

\begin{tabular}{|c|c|c|c|c|c|c|c|c|c|}
\hline \multirow{2}{*}{$\begin{array}{l}\text { Product } \\
\text { Soko Mjinga }\end{array}$} & \multirow{2}{*}{$\begin{array}{l}\text { Points } \\
\text { allocate } \\
\text { (P) }\end{array}$} & \multirow{2}{*}{$\begin{array}{l}\text { Points in } \\
\text { Bicycle } \\
\text { Equiv- } \\
\text { alents } \\
(\mathrm{P} / 3)\end{array}$} & \multirow{2}{*}{$\begin{array}{l}\text { Value } \\
(P / 3 \\
\times 3000)\end{array}$} & \multicolumn{5}{|c|}{$V / T(1+r)(T-t)$} & \multirow{2}{*}{$\begin{array}{l}\text { Average } \\
\text { Annual } \\
\text { Value (KSh.) }\end{array}$} \\
\hline & & & & Year 4 & Year 3 & Year 2 & Year 1 & Year 0 & \\
\hline Medicine & 12 & 4 & 12000 & 2472 & 2546.2 & 2622.6 & 2701.22 & 2782.26 & 2624.84 \\
\hline $\begin{array}{l}\text { Building } \\
\text { materials }\end{array}$ & 9 & 3 & 9000 & 1854 & 1909.6 & 1966.9 & 2025.92 & 2086.69 & 1968.63 \\
\hline Firewood & 11 & 3.7 & 11100 & 2286.6 & 2355.2 & 2425.9 & 2498.63 & 2573.59 & 2427.97 \\
\hline Honey & 8 & 2.7 & 8100 & 1668.6 & 1718.7 & 1770.2 & 1823.32 & 1878.02 & 1771.77 \\
\hline Grazing & 6 & 2 & 6000 & 1236 & 1273.1 & 1311.3 & 1350.61 & 1391.13 & 1312.42 \\
\hline Food & 6 & 2 & 6000 & 1236 & 1273.1 & 1311.3 & 1350.61 & 1391.13 & 1312.42 \\
\hline Khat & 1 & 0.3 & 900 & 185.4 & 190.96 & 196.69 & 202.59 & 208.67 & 196.86 \\
\hline Hunting & 5 & 1.7 & 5100 & 1050.6 & 1082.1 & 1114.6 & 1148.02 & 1182.46 & 1115.56 \\
\hline Charcoal & 3 & 1 & 3000 & 618 & 636.54 & 655.64 & 675.31 & 695.56 & 656.21 \\
\hline Timber & 4 & 1.3 & 3900 & 803.4 & 827.5 & 852.33 & 877.9 & 904.23 & 853.07 \\
\hline Bicycle & 3 & & & & & & & & \\
\hline Total & & & & & & & & & 14239.74 \\
\hline \multicolumn{10}{|l|}{ Kirie } \\
\hline Medicine & 15 & 5 & 15000 & 3090 & 3182.7 & 3278.2 & 3376.53 & 3477.82 & 3281.05 \\
\hline $\begin{array}{l}\text { Building ma- } \\
\text { terials }\end{array}$ & 13 & 4.3 & 12900 & 2657.4 & 2737.1 & 2819.2 & 2903.81 & 2990.93 & 2821.7 \\
\hline Firewood & 10 & 3.3 & 9900 & 2039.4 & 2100.6 & 2163.6 & 2228.51 & 2295.36 & 2165.49 \\
\hline Honey & 7 & 2.3 & 6900 & 1421.4 & 1464 & 1508 & 1553.2 & 1599.8 & 1509.28 \\
\hline Grazing & 4 & 1.3 & 3900 & 803.4 & 827.5 & 852.33 & 877.9 & 904.23 & 853.07 \\
\hline Food & 6 & 2 & 6000 & 1236 & 1273.1 & 1311.3 & 1350.6 & 1391.13 & 1312.42 \\
\hline Khat & 2 & 0.7 & 2100 & 432.6 & 445.58 & 458.95 & 472.71 & 486.9 & 459.35 \\
\hline Hunting & 9 & 3 & 9000 & 1854 & 1909.6 & 1966.9 & 2025.92 & 2086.69 & 1968.63 \\
\hline Charcoal & 9 & 3 & 9000 & 1854 & 1909.6 & 1966.9 & 2025.92 & 2086.69 & 1968.63 \\
\hline Timber & 8 & 2.7 & 8100 & 1668.6 & 1718.7 & 1770.2 & 1823.32 & 1878.02 & 1771.77 \\
\hline Bicycle & 3 & & & & & & & & \\
\hline Total & & & & & & & & & 18111.37 \\
\hline
\end{tabular}
rate of $3 \%$, and a bicycle lifespan of about 5 years.

est study. Godoy et al. (1993) describe this as the most accurate method of valuing the products extracted from the forest, and ascribes to identifying, counting, weighing and measuring the products as they enter the village. Unfortunately this is limited in its applicability in the case of
Kiang'ombe where the users are scattered in different villages.

In trying to understand the Kiang'ombe community, wealth ranking of the households was done before carrying out the interviews. This was thought important because eco- 
nomic status of the community living around forests in- especially when valuing forest resources that are used fluences exploitation of forest resources (Hot Springs within the household, and recommended the use of conWorking Group 1995), making it necessary to understand tingent valuation and costless choice method. The use of the community in order to understand their valuation of participatory environmental valuation technique allows vilthe wild resources. In his work, Bereket Kebede (2007) lagers to express the value of forest products within the notes that a systematic analytical framework for analysis context of their own perceptions, needs and priorities rather and interpreting information from wealth ranking exercise than through conventional cash-based techniques (Emercan contribute to a better understanding of the economic ton 1996a).

and cultural values people attach to different resources.

Well-being ranking is a participatory method that uses lo- The use of PEV was logical in valuing household use of forcal criteria to highlight economic diversity (Guijt \& Hinch- est products in Mbeere because there were no formal recliffe 1998). cords of forest use. In addition, because of a ban imposed on the collection of firewood, cultivation in the forest, log-

To demonstrate the significance of local forest use, Emer- ging and grazing by the local administration and the District ton has shown the domestic forest use of Mt. Kenya as Forest Office, people living around Kiang'ombe hill would being worth up to $\$ 7$ million a year, four times as much not openly admit engaging in these activities. Godoy et al. as the commercial logging value of the forest and more (1993) and Chopra (1993), recommend monitoring forest than the potential value of forest land under agriculture. These local use values provide an important economic and development justification for conservation (Emerton 1997b). And as Dalle \& Potvin (2004) note, participatory methods have been shown to be useful tools for stimulation of local participation in conservation and for identification of conservation concerns. This therefore can be used as an approach to safeguard resources of Kiang'ombe hill.

The most difficult part of valuation is assigning the products a monetary value (Godoy et al. 1993). Emerton (1996a) noted that cash measures or conventional valuation methods have little relevance to the rural subsistence economies,

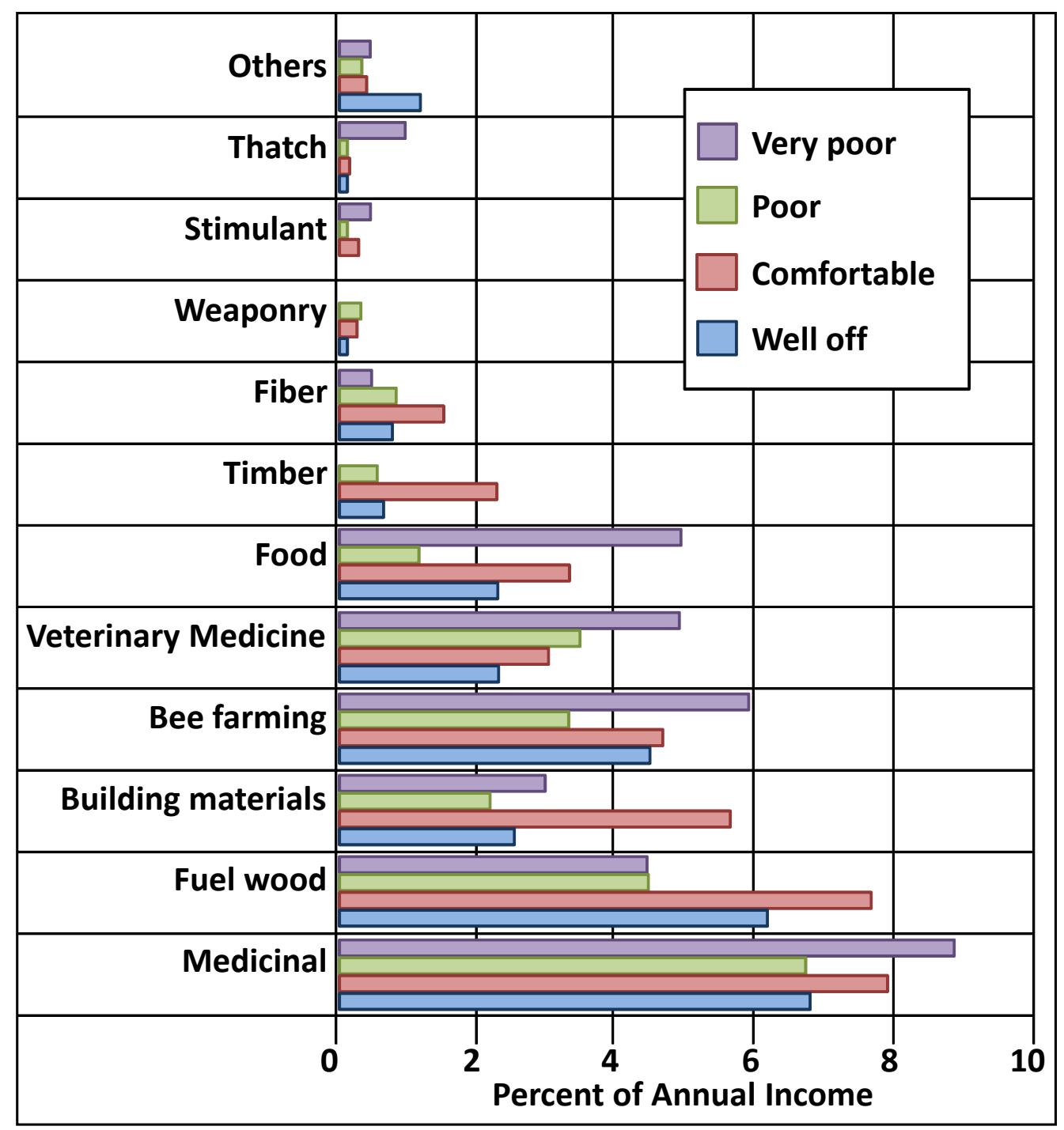

Figure 3. Wealth levels and forest resource dependence per household of people living near Kiang'ombe hill forest, Mbeere District, Kenya. 


\section{Ngugi et al. - The Contribution of Forest Products to Dryland Household Economy: The case of Kiang'ombe hill forest, Kenya}

resource utilisation and pricing for valuation by use of substitutes to, or identifying people's cash willingness to pay for forest products. These methods of valuation are good where market prices of forest products are feasible but would not have been appropriate for Kiang'ombe. This was because, firstly, barter was still practiced and therefore cash willingness to pay for what was perceived as free or God given would have been disregarded. Secondly, and as Emerton (1997a,b) observes, it is difficult to carry out observation over a long enough period or in sufficient detail to get a clear idea of the quantities of forest products involved, therefore most of the conventional cash-based economic valuation techniques have limited validity (Godoy et al. 1993, Gunatilake et al. 1993). The valuation used here designates the average annual value, in Kenya shilling equivalent, per household, which was calculated at a mean of KSh. 16,175.56 (US\$256.8) from Soko Mjinga and Kirie data. This helps one reflect on shortcomings of globalization of trade in which value is imputed to resources only when they enter external markets, meaning, as Posey (1999) observes, existing non-monetary values recognized by local communities are ignored, despite knowledge that local biodiversity provides essential elements for survival, some of which are assumed to be free for the taking, like knowledge on medicinal plants by bio-prospectors. From household surveys, the average annual income per household was found to be KSh. 29,185.72 (US\$463.3) (Table 2). This annual income was based on income from both forest and farm produce, including livestock farming. This shows that the forest contributes about $55.42 \%$ to the household income, and confirmed the high dependency of Kiang'ombe people on forest resources.

The focus in this study was to evaluate the importance of Kiang'ombe hill forest to the Mbeere people of Kiang'ombe by attempting to use the local plant use knowledge to quantitatively value the forest. This was complimented by an understanding of the people's livelihood during household visits and PRA meetings. Local knowledge has been recommended as a tool for rapid assessment of plant resources (Dalle \& Potvin 2004, Hellier et al. 1999). Dalle and Potvin (2004) cite advantages in that one collects data on large number of species including less abundant ones using less labour intensive methods.

Dependence on the forest seemed to be little influenced by the affluence of the people. The well to do households did not seem to depend heavily on the forest like the poor households, but the forest products still formed a considerable portion of their income (Figure 3)

Absolute value of forest resources seems to be positively correlated with knowledge about the forest and its resources. It would therefore be important to carry out a complete survey of the forest and its resources to establish its potential as its contribution to the household economy is quite significant.
Local people's dependency on the forest for livelihood including water and medicine cannot be ignored or wished away and understanding forest income dependence is important in guiding plans for forest products use at all levels of governance. It would therefore be recommended that conservation strategies be developed that will involve the local people in the management of the Kiang'ombe hill forest in order to protect the forest as a water catchment area and provide for sustainable livelihood. This can be done by encouraging the local community to cultivate more of the useful trees both for household use and sale. Management activities should support indigenous tree planting for restoration of degraded forest habitat and support local community wood fuel requirement. The government, through the local authority, should work towards reduction of population pressure on forest resources by establishing critical synergy between population increase and environmental preservation probably through partnerships with local community based and non-governmental organizations in the field of health and nutrition to tackle family planning and education on forest destruction and banning of some forest products use and activities, as have been done before by the Kenya forest service, should be minimal, and where necessary, should provide alternative resources as identified with the local communities.

\section{Literature Cited}

Beentje, H.J. 1990. The forest of Kenya. Pp. 265-286 in Proceedings of the 12th Plenary Meeting of AETFAT, Symposium II. Edited by H.-D. Ihlanfeldt. Volume 23a. Mitteilungen aus dem Institut für Allgemeine Botanik Hamburg.

CBS. 2001. Central Bureau of Statistics. The 1999 Kenya Population and Housing Census. Ministry of Finance and Planning, Nairobi, Kenya.

Chopra, K. 1993. The value of non-timber forest products: An estimation for tropical deciduous forests in India. Economic Botany 47:251-257.

Cunningham, A.B. 2001. Applied Ethnobotany: People, wild plant use and conservation. Earthscan Publications Ltd., London.

Dalle, S.P. \& C. Potvin. 2004. Conservation of useful plants: An evaluation of local priorities from two indigenous communities in Eastern Panama. Economic Botany 58:38-57.

Delang, C.O. 2006. Not just minor products: The economic rationale for the consumption of wild food plants by subsistence farmers. Ecological Economics 59:64-73.

Emerton, L. 1996a. Valuing the Environment: Case studies from Kenya. African Wildlife Foundation, Nairobi, Kenya. 
Emerton, L. 1996b. Participatory environmental valuation: Subsistence forest use around the Aberdares, Kenya. Participatry Learning and Action Notes 26:6-10.

Emerton, L. 1996c. Valuing the subsistence use of forest products in Oldoinyo Orok Forest, Kenya. Rural Development Forestry Network Paper 19e, London, U.K. www.odi.org.uk/resources/download/736.pdf.

Emerton, L. 1997a. Livelihood Values and Conservation in Mount Kenya Forest. Unpublished Paper Presented in a conference on Africa Rainforest and Conservation of Biodiversity held in Limbe Botanic Garden, Cameroon.

Emerton, L. 1997b. Livelihood values and conservation in Mount Kenya Forest. Pp. 134-139 in Proceedings of the Limbe Conference on African Rainforests and the Conservation of Biodiversity. Edited by S. Doolan. Limbe Botanic Garden, Cameroon, 17-24 January. Earthwatch Europe, Oxford, U.K.

Godoy, R. \& R. Lubowski. 1992. Guidelines for the economic valuation of non timber tropical forest products. Current Anthropology 33:423-433.

Godoy, R., R. Lubowski \& A. Markandya. 1993. A method for the economic valuation of non-timber tropical forest products. Economic Botany 47:220-233.

GOK. 2002. Government of Kenya. Mbeere District Development Plan, 2002-2008. Government Printers, Nairobi, Kenya.

Groombridge, B. 1992. Editor of Global Biodiversity: Status of earth's living resources. Compiled by World Conservation Monitoring Centre (WCMC). Chapman and Hall, London, U.K.

Guijt, I. \& F. Hinchcliffe. 1998. Participatory Valuation of Wild Resources: An overview of the hidden harvest methodology. International Institute for Environment and Development, London.

Gunatilake, H.M., D.M.A.H. Senaratne \& P. Abeygunawardena. 1993. Role of non-timber forest products in the economy of peripheral communities of Knuckles National Wilderness Area of Sri Lanka: A farming systems approach. Economic Botany 47:275-281.

Hellier, A., A.C. Newton \& S.O. Gaona. 1999. Use of indigenous knowledge for rapidly assessing trends in biodiversity: A case study from Chiapas, Mexico. Biodiversity and Conservation 8:869-889.

Hot Springs Working Group. 1995. Local-Level Economic Valuation of Savanna Woodland Resources: Village cases from Zimbabwe. Research Series Volume 3, Number
2. Sustainable Agriculture Programme, International Institute for Environment and Development, London

Kebede B. 2007. Community Wealth Ranking and Households Surveys: An integrated approach. Q-squared Working Paper 38. University of Toronto, Toronto, Canada.

Martin, G.J. 1995. Ethnobotany: A Methods Manual. Chapman \& Hall, London.

Matiru, V. 2000. Forest Cover and Forest Reserves in Kenya: Policy and practice. Revised. IUCN Eastern Africa Programme, Forest and Social Perspectives in Conservation. Working Paper No. 5. IUCN, Nairobi, Kenya.

Ngugi, G.W. 2007. Ethnobotanical Survey of Kiang'ombe Forest, Kenya: Floristic inventory, utilisation and conservation status. Unpublished M.Sc. Thesis, Kenyatta University, Nairobi, Kenya

Nijkamp, P., G. Vindigni \& P.A.L.D. Nunes. 2008. Economic valuation of biodiversity: A comparative study. Ecological Economics 67:217-231.

Nunes, P.A.L.D. \& J.C.J.M. van den Bergh. 2001. Economic valuation and biodiversity: Sense or nonsense? Ecological Economics 39:203-222.

Padilla, J. \& M.P.R. Rina. 1998. Economic valuation of biodiversity: A preliminary survey of current thinking and applications. People, Earth and Culture. Los Baños, Laguna, The Philippines.

Posey, D.A. 1999. Editor of Cultural and Spiritual Values of Biodiversity. United Nations Environmental Programme, Nairobi, Kenya.

Riley, B.W. \& D. Brokensha. 1988. The Mbeere in Kenya: Volume 1. Changing rural ecology. University Press of America, Lanham, Maryland.

Rosales, R., M. Kallesoe, P. Gerrard, P. Muangchanh, S. Phomtavong \& S. Khamsomphou. 2003. The Economic Returns from Conserving Natural Forests in Sekong, Lao $P D R$. IUCN Asia Regional Environmental Economics Programme and WWF Laos Country Office, Vientiane, Laos.

Shackelton, S.E., C.M. Shackelton, T.R. Netshiluvhi, B.S. Geach, A. Ballance \& D.H.K. Fairbanks. 2002. Use patterns and values of savanna resources in three rural villages in South Africa. Economic Botany 56:130-146.

Waiganjo, F.W. 1999. Forest Plants Used in Ragati, Mt. Kenya: Their taxonomy, exploitation, economic values and conservation status. M.Sc. thesis. Kenyatta University, Nairobi, Kenya. 


\section{Economy: The case of Kiang'ombe hill forest, Kenya}

Wass, P. 1995. Kenya's Indigenous Forests: Status, man- World Factbook. 2010. Kenya. United States, Central Inagement and conservation. International Union for Con- telligence Agency. https://www.cia.gov/library/publicaservation of Nature, Nairobi, Kenya.

tions/the-world-factbook/geos/ke.html 
Appendix 1. Household survey datasheet used at Kiang'ombe hill forest, Kenya. (Ngugi 2007)

Date:

Qnaire No.

A. Background information

Respondent's name:

Village:

Community:

How long have you lived in this village?

Where did you originally come from?

\section{B: Household characteristics:}

\begin{tabular}{|l|l|l|l|l|l|l|}
\hline Respondent & Gender & Age & Marital Status & Education Level & Main Occupation & $\begin{array}{l}\text { Relationship to } \\
\text { household head }\end{array}$ \\
\hline Person 1 & & & & & & \\
\hline Person 2 & & & & & & \\
\hline & & & & & & \\
\hline & & & & & & \\
\hline
\end{tabular}

Size of family

\begin{tabular}{|l|l|}
\hline Children & \\
\hline Adults & \\
\hline Total & \\
\hline
\end{tabular}

\begin{tabular}{|l|l|}
\hline Code & Character states \\
\hline Gender & 1=Male, 2=Female \\
\hline Age & 1=Adult, 2=Youth, 3=Children \\
\hline Marital Status & 1=Married, 2=Single, 3=Widowed, 4=divorced \\
\hline Education Level & 1=no formal, 2=Primary, 3=Secondary, 4=College, 5=Adult education, 6=Other (specify) \\
\hline Main occupation & 1=No occupation, 2=Farmer, 3=Others (specify) \\
\hline $\begin{array}{l}\text { Relationship to } \\
\text { household head }\end{array}$ & 1=Husband, 2=wife, 3=daughter, 4=son, 5=Relative, 6=Non relative \\
\hline Size of family & 1=Adults, 2=Children \\
\hline
\end{tabular}

\section{C: Overview of Household Resources:}

\begin{tabular}{|l|l|}
\hline Resource type & No/size \\
\hline Land (acres) & \\
\hline Crops cultivated & \\
\hline Livestock -Cattle & \\
\hline -Sheep & \\
\hline -Goats & \\
\hline -Donkeys & \\
\hline -Chicken & \\
\hline -Others (specify) & \\
\hline
\end{tabular}




\section{Ngugi et al. - The Contribution of Forest Products to Dryland Household Economy: The case of Kiang'ombe hill forest, Kenya}

\section{D: Sources of Income}

\begin{tabular}{|l|l|l|l|}
\hline Source & Unit Price( e.g., tins, kg, bundle etc.) & Quantity sold & Amount (KSh) \\
\hline Crop sale (Name the crop) & & & \\
\hline & & & \\
\hline $\begin{array}{l}\text { Livestock sales (name the } \\
\text { livestock/ product sold }\end{array}$ & & & \\
\hline & & & \\
\hline & & & \\
\hline Other sources of income & & & \\
\hline Local brew & & & \\
\hline Casual labour & & & \\
\hline Formal employment & & & \\
\hline Remittances & & & \\
\hline Others (specify) & & & \\
\hline & & & \\
\hline
\end{tabular}

\section{E: Sources of household food.}

\begin{tabular}{|l|l|l|}
\hline Source & Type/name & Amount (kgs, bags, tins etc) \\
\hline Own Production & 1 & \\
\hline & 2 & \\
\hline Purchased & 1 & \\
\hline & 2 & \\
\hline Others (specify) & 1 & \\
\hline & 2 & \\
\hline
\end{tabular}

\section{F: Plant Utilization}

Livestock Farming

1. For the animals named above, how do you feed them
(1) Zero grazing
(2) Pasture

2. Where do you get the grass or feed from
(1) Cultivated
(3) Others (specify)
(2) From the forest

3. How do you treat animals when they fall sick?
(1) Modern veterinary medicines
(3) Others (specify)
(2) Traditional medicine/medicinal plants

4. If you use medicinal plants, what plants do you use to treat animals?

\begin{tabular}{|l|l|l|l|l|}
\hline Name of plant & Part used & Method of harvesting & Method of administration & Disease cured \\
\hline & & & & \\
\hline
\end{tabular}

5. Where do you get the medicinal plants for animal treatment?
(1) From cultivation/near homestead
(3) From market
(2) From the forest
(4) Others (specify)

\section{Household usage}

6. What do you use for cooking?
(1) Charcoal
(2) Fuel wood
(3) Others (Specify) 
7. Where do you get Charcoal/Fuel Wood?
(1) Cultivated
(3) From the market
(2) From the forest
(4) Others (specify)

8. Which tree do you use or prefer for energy use (charcoal/fuel wood)?

\begin{tabular}{|l|l|l|}
\hline Name of plant & Reasons for preference & Rank \\
\hline & & \\
\hline
\end{tabular}

9. Note the material used for roofing
(1) Grass
(3) Tiles
(2) Iron Sheet
(4) Others (specify)

10. If (1) where do you get thatch grass from
(1) From the forest
(2) Others (specify)

11. Do you keep bees?
(1) Yes
(2) No

12. If yes, what trees do you use for beehive?

\begin{tabular}{|l|l|l|l|l|l|}
\hline Name of plant & For beehive & To hang the beehive & Reasons & & Rank \\
\hline & & & & \\
\hline
\end{tabular}

13. How do you harvest honey?

14. What is the purpose of honey harvested?
(1) For sale (note the cost)
(2) For consumption
(3) For brewing
(4) Others (specify)

15. Do you obtain any plant for food from the forest?
(1) Yes
(2) No

16. If yes what plants are used for food?

\begin{tabular}{|l|l|l|l|l|}
\hline Name of plant & Part used & $\begin{array}{l}\text { Method of } \\
\text { harvesting }\end{array}$ & $\begin{array}{l}\text { Method of } \\
\text { preparation }\end{array}$ & $\begin{array}{l}\text { Availability (month) } \\
\& \text { comments }\end{array}$ \\
\hline & & & & \\
\hline
\end{tabular}

17. If you collect, give reasons for the collection
(1) Part of the diet
(3) Source of income (where do you sell and for how much)
(2) Option during shortage
(4) Medicinal

18. How many times do you harvest the product per week when available?

\begin{tabular}{|l|l|l|l|}
\hline Product & Times & Quantity collected & Cost (rough estimation) \& where sold \\
\hline & & & \\
\hline
\end{tabular}

19. How regularly do you rely on the forest?

(1) During the hunger season (specify mon.) (3) Throughout the year

(2) Seasonally (specify) (4) Other times (specify)

20. What types of food do use during the hunger period?

21. Where do you get the above-mentioned foods?
(1) Government aid/relief food
(4) Own reserve
(2) From forest
(5) Others (specify)
(3) From Market 


\section{Ngugi et al. - The Contribution of Forest Products to Dryland Household Economy: The case of Kiang'ombe hill forest, Kenya}

22. How do you compare the availability of food now from 10 years ago?
(1) Decreasing
(3) Same
(2) Increasing

23. What do you think is the reason for the above answer?

24. Where do you get your treatment?
(1) Modern medicine
(3) Self treat with medicinal plants
(2) Traditional practitioner
(4) Others (specify)

25. If (3) which plants do you use for treatment?

\begin{tabular}{|l|l|l|l|l|}
\hline Name of plant & Part used & Method of harvesting & $\begin{array}{l}\text { Method of } \\
\text { administration }\end{array}$ & Disease cured \\
\hline & & & & \\
\hline
\end{tabular}

26. Beside you, who else is involved in harvesting?
(1) Husband/Wife
(3) Others (specify)
(2) Children

27. Do you harvest any other forest product for house use or sale (1) Yes $\quad$ (2) No

28. If yes which ones, please list

\begin{tabular}{|l|l|l|l|l|}
\hline $\begin{array}{l}\text { Name of plant/ } \\
\text { product }\end{array}$ & Part used & Method of harvesting & Usage & Comments \\
\hline & & & & \\
\hline
\end{tabular}

29. Would you like Kiang'ombe Forest to be gazetted? Give reasons

30. For what purpose is the forest burnt and who burns?

\section{G: HERBAL MEDICINE USE}

(To be filled if not contented with response to $Q 24$ )

1. Do you use herbal medicine to cure diseases? Yes.....1 No ........2

2. If yes, which of these are from the forest?

\begin{tabular}{|l|l|l|l|l|}
\hline Name of plant & Method of harvesting & Part(s) Used & $\begin{array}{l}\text { Method of } \\
\text { Administration }\end{array}$ & Diseases Cured \\
\hline & & & & \\
\hline
\end{tabular}

3. How often do you collect medicinal plants from the forest?
1.A few times a week
2. A few times in a month
3. A few times in a year

4. Under what condition would you decide to go to the hospital/clinic for treatment instead of using herbal Medicine?

5. Do you collect herbal medicine for sale? Yes.........1: No ........2

6. If yes, how much did you earn from this sale?
Last week
1: Last month.
2: $\quad$ Last year ..3

7. Do you buy herbal medicine?

Yes.

1: No

2

8. If yes, how much did you spend on herbal medicine?
Last week 1:
Last month
2: Last year . .3 

9. Have you planted or preserved medicinal plants in your garden?
Yes .......
No $\ldots . . .2$
10. If yes, which ones?

H: STATUS OF LOCAL UTILISATION OF FOREST PRODUCTS.

(section used for the purpose of cross checking the info given above)

1. What products did you collect from the forest in the past?

Medicinal plants ........1: Firewood ........2: Poles/Posts .........3: Fibers .......4: Timber ......5:
Other (please specify) .........6

2. Do you collect any of these products at present? Yes .......1: No ...... 2

3. If yes, what products do you get from the forest? (Rank, starting with the most important)

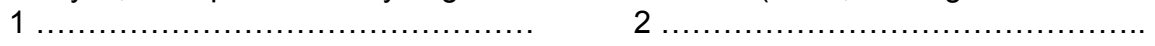

4. Why is (1) most important?

5. Why is (2) most important?

6. Please rank for me the plants mentioned under the following categories and give reasons for the 1 st three ranks.

$\begin{array}{lll}\text { Medicinal } & \text { Food } & \text { Timber } \\ \text { Fiber } & \text { Poles/Posts } & \text { Thatching grass }\end{array}$

(Note):

Type of dwelling:

Temporary .................... 1

Semi - permanent ........... 2

Permanent ................... 3

Household wealth (as ranked by the villager elders):

Rich ............. W 1 Well-off ............ 2

Comfortable ...... $3 \quad$ Poor .............. 4

Very poor ......... 5 